\title{
Feasibility and Accuracy of Molecular Testing in Specimens Obtained with Small Biopsy Forceps: Comparison with the Results of Surgical Specimens
}

\author{
Masahide Oki $^{a}$ Yasushi Yatabe $^{c}$ Hideo Saka $^{a}$ Chiyoe Kitagawa ${ }^{a}$ \\ Yoshihito Kogure $^{a}$ Shu Ichiharab Suzuko Moritani ${ }^{b}$ \\ Departments of a Respiratory Medicine and ${ }^{b}$ Pathology, Nagoya Medical Center, ${ }^{c}$ Department of Pathology and \\ Molecular Diagnostics, Aichi Cancer Center, Nagoya, Japan
}

\section{Key Words}

Bronchoscopy · Ultrathin bronchoscopy · Genotyping ·

$E G F R \cdot K R A S \cdot A L K \cdot$ Endobronchial ultrasound

\begin{abstract}
Background: During bronchoscopy, small biopsy forceps are increasingly used for the diagnosis of peripheral pulmonary lesions. However, it is unclear whether the formalinfixed paraffin-embedded specimens sampled with the small biopsy forceps are suitable for the determination of genotypes which become indispensable for the management decision regarding patients with non-small cell lung cancer. Objectives: The aim of this study was to evaluate the feasibility and accuracy of molecular testing in the specimens obtained with 1.5-mm small biopsy forceps. Methods: We examined specimens in 91 patients, who were enrolled in our previous 3 studies on the usefulness of thin bronchoscopes and given a diagnosis of non-small cell lung cancer by bronchoscopy with the $1.5-\mathrm{mm}$ biopsy forceps, and then underwent surgical resection. An experienced pathologist examined paraffin-embedded specimens obtained by bronchoscopic biopsy or surgical resection in a blind fashion on epidermal growth factor receptor (EGFR) mutations, anaplastic lymphoma kinase (ALK) rearrangements and KRAS mutations. Results: Twenty-five (27\%), 2 (2\%) and 5 (5\%) patients had an EGFR mutation, ALK rearrangement and KRAS
\end{abstract}

mutation, respectively, based on the results in surgical specimens. EGFR, ALK and KRAS testing with bronchoscopic specimens was feasible in 82 (90\%), 86 (95\%) and 83 (91\%) patients, respectively. If molecular testing was feasible, the accuracy of EGFR, ALK and KRAS testing with bronchoscopic specimens for the results with surgical specimens was 98 , 100 and $98 \%$, respectively. Conclusion: The results of molecular testing in the formalin-fixed paraffin-embedded specimens obtained with the small forceps, in which the genotype could be evaluated, correlated well with those in surgically resected specimens.

(c) 2015 S. Karger AG, Basel

\section{Introduction}

Bronchoscopy has been widely used for the diagnosis of peripheral pulmonary lesions; however, the diagnostic yield of conventional bronchoscopy for peripheral pulmonary lesions, particularly small lesions, has not been satisfactory $[1,2]$. Recent modifications of this procedure using some new devices, such as endobronchial ultrasound [3-12], thin bronchoscopes $[8,11,13]$, navigation

Preliminary data were previously presented at the ATS 2013 Annual Meeting in Philadelphia, Pa., USA.

\section{KARGER 125}

(c) 2015 S. Karger AG, Base

0025-7931/15/0893-0235\$39.50/0 
devices $[3,4,6,7,10]$, or a guide sheath $[3-5,7,9,10]$, dramatically increased the diagnostic yield of bronchoscopy, and seem to be reasonable as a first diagnostic test in terms of accuracy and safety $[1,2]$. Traditionally, bronchoscopes with a $2.0-\mathrm{mm}$ working channel have been considered standard, and so 1.8 - or 1.9-mm biopsy forceps which are available for the $2.0-\mathrm{mm}$ working channel have been most widely used [14]. On the other hand, several investigators reported the usefulness of a thin guide sheath for the $2.0-\mathrm{mm}$ working channel $[3-5,7,9-12]$ or thin bronchoscopes with a $1.7-\mathrm{mm}$ working channel $[8$, $11,13]$. The standard-sized biopsy forceps are not available for such modified bronchoscopy, and so $1.5-\mathrm{mm}$ biopsy forceps have been used. The small biopsy forceps are now commercially available and increasingly used in clinical practice. Although the size of samples obtained with the forceps is relatively small, many investigators have reported its good ability to sample tissues for definitive diagnosis [3-5, 7-13].

Recent advancement in the field of genomics has enabled the development of some useful molecular targets such as epidermal growth factor receptor (EGFR)-tyrosine kinase inhibitors or anaplastic lymphoma kinase (ALK) inhibitors. EGFR mutations and $A L K$ rearrangements have been demonstrated to be a reliable predictive biomarker of the efficacy of the EGFR-tyrosine kinase inhibitors and ALK inhibitors, respectively [1518]. Thus, the determination of genotypes has become indispensable for the management decision in patients with non-small cell lung cancer (NSCLC) who might potentially benefit from these molecular targets. As a consequence, the diagnosis of NSCLC should include genotyping as well as subtype classification $[1,14,19-$ 22]. Although various bronchoscopic specimens are available for genotyping [23-30], formalin-fixed paraffin-embedded specimens have been most widely employed in clinical practice because of their easy use, long-time storage and low costs [14]. Although the feasibility and reliability of genotyping in formalin-fixed paraffin-embedded bronchoscopic specimens obtained with standard-size forceps are well-established [23], it remains unclear whether the specimens sampled with the small biopsy forceps are suitable for genotyping. As a consequence, the clinical use of the small biopsy forceps in place of the standard-sized biopsy forceps during bronchoscopy has not yet been justified. The aim of this study was to evaluate the feasibility and accuracy of genotyping in the relatively small specimens obtained with the $1.5-\mathrm{mm}$ small biopsy forceps by comparing large surgical specimens.

\section{Patients and Methods}

\section{Patients}

We reviewed our previous 3 studies $[8,11,13]$ conducted from 2005 to 2009, which evaluated the diagnostic yield of thin bronchoscopy or bronchoscopy with a thin guide sheath for peripheral pulmonary lesions. In those studies, $1.5-\mathrm{mm}$ small biopsy forceps (FB-32D/XBO1-951/FB-233D; Olympus; Tokyo, Japan) were used for sampling specimens. Of the 372 patients analyzed in those studies, 94 were given a diagnosis of NSCLC by bronchoscopy and underwent surgical resection. Informed consent was obtained from live patients, and 3 patients refused to participate in this study. Thus, a total of 91 patients were enrolled and analyzed. The institutional review board of Nagoya Medical Center approved this study (identifier: 2011-482).

\section{Molecular Testing}

At the Department of Pathology, Nagoya Medical Center, six 4- $\mu$ m-thick unstained sections from bronchoscopic biopsy and corresponding surgical specimens were prepared, and were sent to the Molecular Pathology Laboratory of the Aichi Cancer Center Hospital. Because this study was conducted simulating the routine diagnosis, individual samples were processed as usual. The unstained slides, of which identification numbers were randomly labeled, were submitted to the pathologists. Although the specimens could be differentiated as to whether they were obtained by surgery or bronchoscopy, the correspondences between surgical and bronchoscopic specimens were completely blinded. After confirmation of tumor cell contents on re-sectioned slides for molecular testing, genotypes of EGFR, KRAS and ALK were assessed. For EGFR mutation, the Cycleave polymerase chain reaction (PCR) technique and fragment analysis were used for the detection of EGFR L858R and exon 19 deletion, respectively, as described previously [31]. Similarly, KRAS mutation was analyzed by the Cycleave PCR technique. $A L K$ gene rearrangements were screened with immunohistochemistry using sensitive ALK antibody (clone 5A4, Santa Cruz, Calif., USA) and the EnVision FLEX+ detection system (Dako, Copenhagen, Denmark). When positive or equivocal results were obtained with the immunohistochemistry, further confirmatory fluorescent in situ hybridization was carried out using an $A L K$ break-apart probe (Vysis LSI ALK Dual Color, Break Apart Rearrangement Probe; Abbott Molecular, Abbott Park, Ill., USA) as previously described $[32,33]$.

\section{Results}

\section{Patients}

Bronchoscopic specimens and surgical specimens from a total of 91 Japanese patients (63 males and $28 \mathrm{fe}$ males; median age 65 ; range $25-83$ years) were retrospectively evaluated. Sixty-four patients had adenocarcinoma, 21 had squamous cell carcinoma, 3 had large cell carcinoma, 2 had a combination of adenocarcinoma and squamous cell carcinoma, and 1 had a combination of small cell carcinoma and adenocarcinoma. The median lesion size in the longest diameter on CT was $28 \mathrm{~mm}$ (range 
Table 1. Results of EGFR testing

\begin{tabular}{lll}
\hline Variable & \multicolumn{2}{l}{ Type of specimens } \\
\cline { 2 - 3 } & $\begin{array}{l}\text { bronchoscopic } \\
\text { specimens }\end{array}$ & $\begin{array}{l}\text { surgical } \\
\text { specimens }\end{array}$ \\
\hline Specimens examined & 86 & 91 \\
Specimens with EGFR mutations & 21 & 25 \\
Fragment analysis & & \\
$\quad$ Exon 19 & 13 & 15 \\
$\quad$ Wild type & 71 & 15 \\
$\quad$ No PCR amplification & 2 & 10 \\
Cycleave PCR & & 81 \\
$\quad$ L858R & 8 & 0 \\
Wild type & 74 & \\
$\quad$ No PCR amplification & 4 & \\
\hline
\end{tabular}

Data are presented as number.

11-65 mm). Routine hematoxylin and eosin stain had been performed, followed by further immunohistochemical stains for definitive diagnosis in bronchoscopic specimens at the time of diagnosis in 20 of 91 (22\%) patients. After NSCLC was diagnosed with bronchoscopic biopsy using a $1.5-\mathrm{mm}$ biopsy forceps, 77 patients underwent lobectomy, 9 segmentectomy, and 5 wedge resection. The pathological tumor and nodal stages based on the surgical procedures were as follows: $\mathrm{T} 1$ in 33, T2 in 40, T3 in 16 and T4 in 2; N0 in 52, N1 in 18, N2 in 12 and no nodal dissection or sampling in 9.

\section{Re-Evaluation of Sectioned Slides for Molecular Testing}

All specimens essentially contained tumor cells diagnosed as cancer, but tumor cells might have disappeared with slides re-sectioned for molecular analysis. Therefore, we checked and confirmed sufficient contents of tumor cells for molecular testing in 86 of 91 (95\%) biopsy specimens, and all (100\%) surgical specimens.

\section{Mutations}

Results of EGFR mutation detection are shown in table 1. EGFR mutations were detected in the surgical specimens in 25 patients (27\%; exon 19 in 15 patients and L858R in 10 patients). Of the 25 patients, EGFR mutation could not be detected in the bronchoscopic specimens in 4 patients including 2 without analysis of mutations because of specimens with no tumor cells; thus, EGFR mutations were detected in the bronchoscopic specimens in $21(23 \%)$ patients. All patients with EGFR mutations had
Table 2. Results of ALK testing

\begin{tabular}{|c|c|c|}
\hline \multirow[t]{2}{*}{ Variable } & \multicolumn{2}{|c|}{ Type of specimens } \\
\hline & $\begin{array}{l}\text { bronchoscopic } \\
\text { specimens }\end{array}$ & $\begin{array}{l}\text { surgical } \\
\text { specimens }\end{array}$ \\
\hline Specimens examined & 86 & 91 \\
\hline $\begin{array}{l}\text { Specimens with } A L K \text { rearrangements } \\
\text { IHC }\end{array}$ & 2 & 2 \\
\hline Positive & 2 & 2 \\
\hline Equivocal & 1 & 2 \\
\hline Negative & 83 & 87 \\
\hline $\begin{array}{l}\text { FISH (for IHC positive or } \\
\text { equivocal cases) }\end{array}$ & & \\
\hline Positive & 2 & 2 \\
\hline Negative & 1 & 2 \\
\hline
\end{tabular}

Data are presented as number. IHC = Immunohistochemistry; $\mathrm{FISH}=$ fluorescent in situ hybridization. adenocarcinoma. In the surgical specimens, PCR amplification failed in one patient, and so gene analysis for both exon 19 and L858R was feasible in 90 of 91 patients (99\%). In the bronchoscopic specimens, gene analysis was feasible in 82 (excluding no tumor cells in 5 and no PCR amplification with either fragment analysis or Cycleave PCR technique in 4) of 91 patients (89\%). In 81 patients in whom gene analysis with both bronchoscopic and surgical specimens was feasible, the sensitivity, specificity and accuracy for detection of EGFR mutations with bronchoscopic specimens based on the results with surgical specimens was 91, 100 and 98\%, respectively.

Results of $A L K$ gene rearrangement detection are shown in table 2. ALK rearrangements were detected in the surgical specimens in 2 patients (2\%), which corresponded to the results in the bronchoscopic specimens. The 2 patients had adenocarcinoma. The feasibility of $A L K$ testing was $100 \%$ (all 91 patients) in surgical specimens and 95\% (86 of 91 patients) in bronchoscopic specimens. In patients in whom $A L K$ testing was feasible, the accuracy of $A L K$ testing in the bronchoscopic specimens was 100\%.

Results of KRAS mutation detection are shown in table 3. KRAS mutations were detected in the surgical specimens in 5 patients (5\%; G12 mutation in 5 patients). The analysis with bronchoscopic specimens proved KRAS negative in 1 of the $5 K R A S$-positive patients in surgical specimens. In addition, KRAS testing with bronchoscopic specimens resulted in KRAS positive in 1 patient who was judged as KRAS negative in the testing with the surgical specimens (fig. 1). All but 1 $K R A S$-positive patient with squamous cell carcinoma 


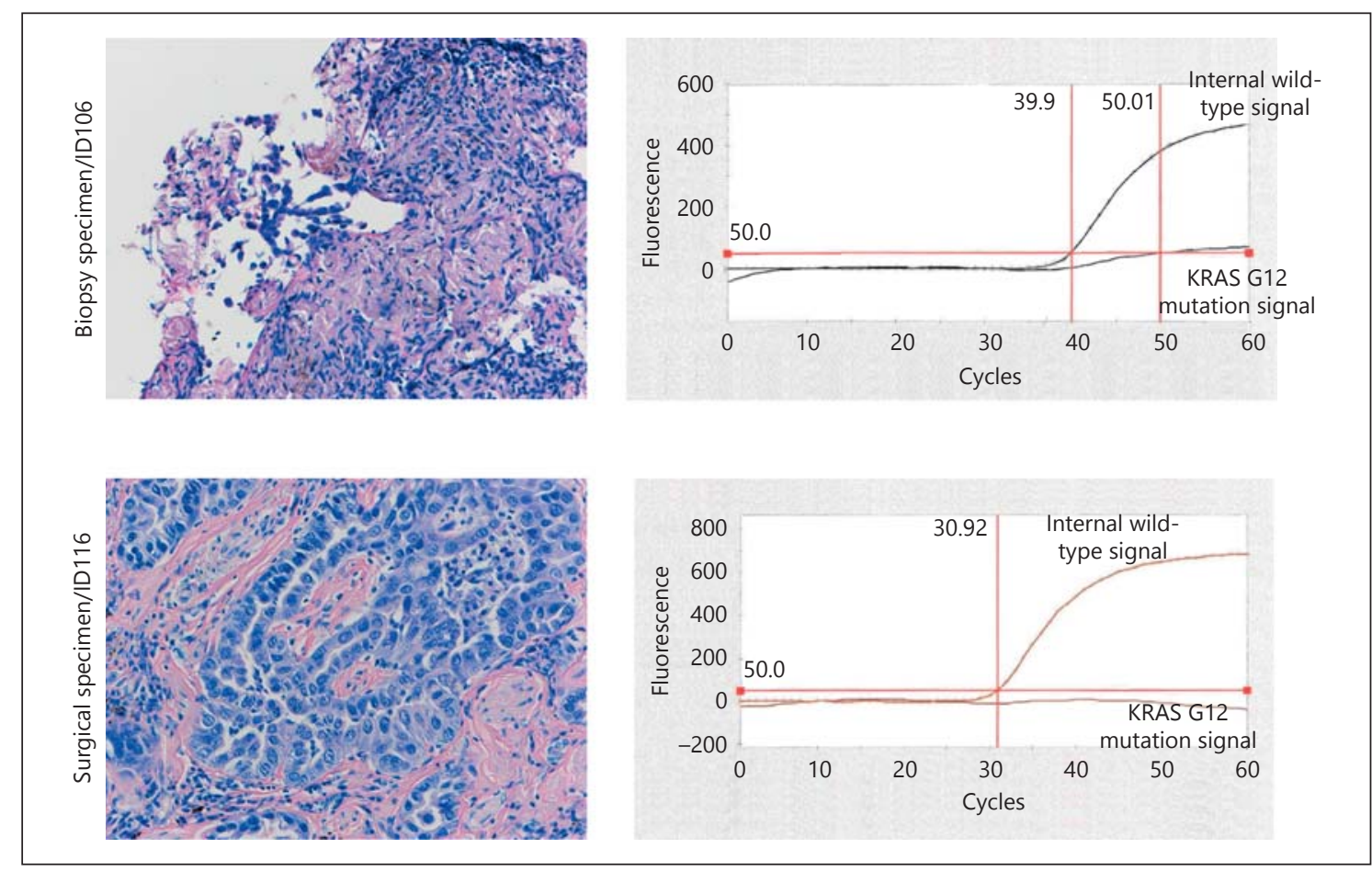

Fig. 1. Bronchoscopic and surgical specimens in a patient showed discordant results in KRAS mutation. A few adenocarcinoma cells were clustered in the bronchoscopic specimen (upper left), appearing to be degenerative. Hematoxylin and eosin staining. $\times 200$, original magnification. The result of KRAS mutation assay (upper right) showed a slight increase in the KRAS G12 mutation signal

Table 3. Results of KRAS testing

\begin{tabular}{lll}
\hline Variable & \multicolumn{2}{l}{ Type of specimens } \\
\cline { 2 - 3 } & $\begin{array}{l}\text { bronchoscopic } \\
\text { specimens }\end{array}$ & $\begin{array}{l}\text { surgical } \\
\text { specimens }\end{array}$ \\
\hline Specimens examined & 86 & 91 \\
Specimens with KRAS mutations & $5^{\mathrm{a}}$ & 5 \\
Cycleave PCR & & 5 \\
G12 & 5 & 85 \\
Wild type & 78 & 1 \\
No PCR amplification & 3 &
\end{tabular}
in 1 .

Data are presented as number. ${ }^{\text {a }}$ Suspected false-positive result

had adenocarcinoma. Testing for KRAS mutations with surgical specimens and bronchoscopic specimens was feasible in 90 of 91 (99\%) patients and 83 of 91 (91\%) patients, respectively. In 82 patients in whom gene analyses with both bronchoscopic specimens and surgical that reached the cutoff value of 50 fluorescence intensity. In contrast, the surgical specimen had a sufficient number of tumor cells (lower left). Hematoxylin and eosin staining. $\times 200$, original magnification. The same specimen had no increase in the signal of KRAS G12 mutation (lower right).

specimens were feasible, the sensitivity, specificity and accuracy of KRAS mutation analysis with bronchoscopic specimens based on the results with surgical specimens were 80, 99 and 98\%, respectively.

A flow chart of patients for molecular testing is shown in figure 2.

Finally, a total of 13 patients had incorrect results with bronchoscopic specimens (no tumor cells in 5, no PCR amplification for either genotyping in 4 , and a false-positive or false-negative result of genotypes based on the results with surgical specimens in 4). Thus, molecular testing using bronchoscopic specimens could be correctly performed in 78 of $91(86 \%)$ patients (bronchoscopic specimens: 78 of 91 vs. surgical specimens: 90 of $91, p=$ 0.001, Fisher's exact test). Immunohistochemical stains with bronchoscopic specimens had been performed at the time of diagnosis in 14 of 78 (18\%) patients with concordant results with surgical specimens and 6 of 13 (46\%) patients with infeasible molecular testing or discordant results with surgical specimens $(\mathrm{p}=0.03$, Fisher's exact test). 


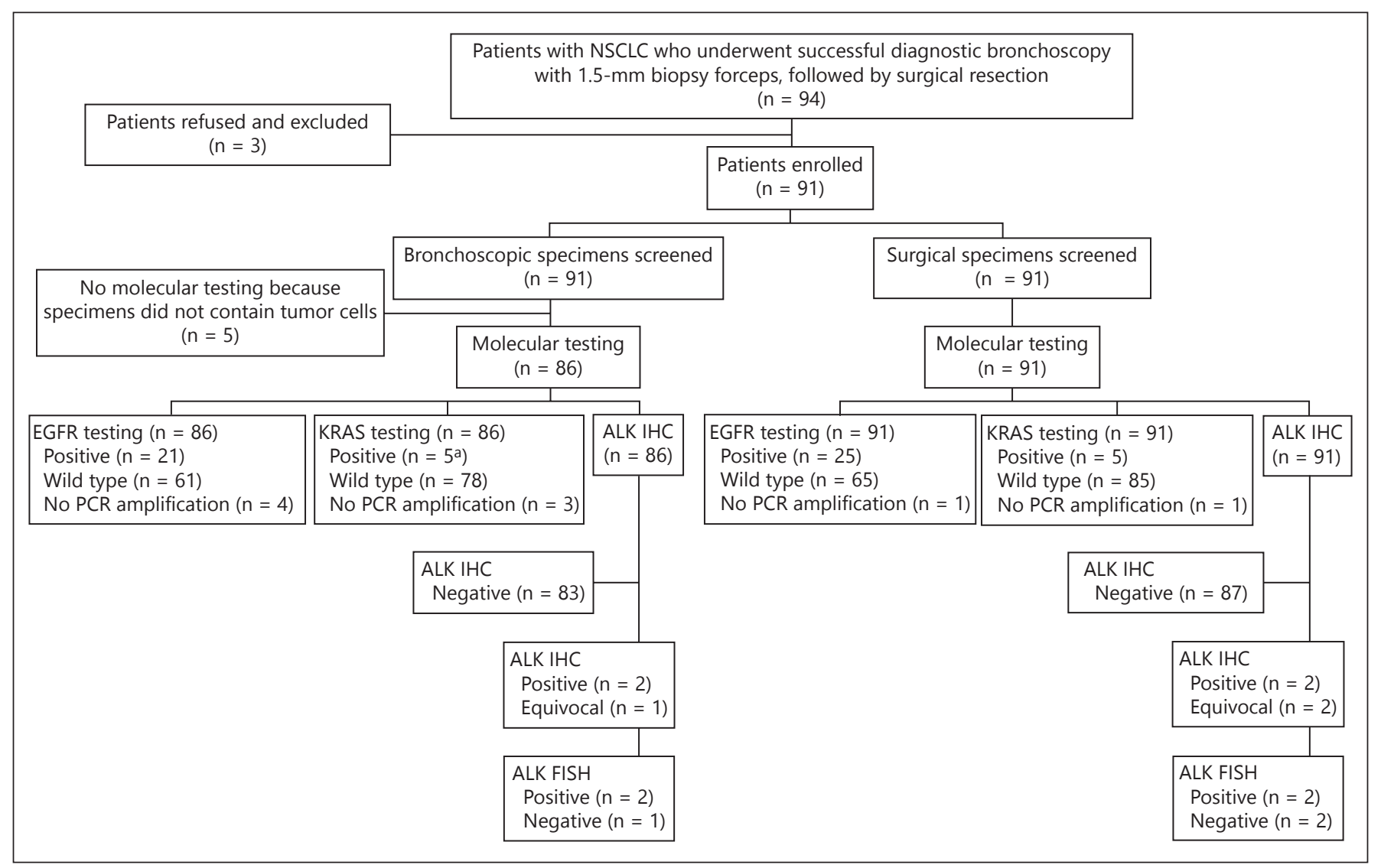

Fig. 2. A flow chart of patients for molecular testing. ${ }^{\text {a }}$ One suspected false-positive result is included. FISH $=$ Fluorescence in situ hybridization; IHC = immunohistochemistry.

The results of 6 patients with positive but discordant results of genotypes between bronchoscopic and surgical specimens are summarized in table 4.

\section{Discussion}

In this study, we investigated the feasibility and accuracy of genotyping within the limited size of specimens obtained with the 1.5 -mm biopsy forceps by comparing surgical specimens. Our study demonstrated the high feasibility of approximately $90 \%$ for genotyping in the specimens obtained with the small biopsy forceps notwithstanding the use of samples which had been preserved for several years. In addition, the results of genotypes in the specimens, which could be examined for the genotypes, correlated well with the results from large specimens obtained with surgical resection. To our knowledge, this is the first study to evaluate the feasibility and accuracy of genotyping in the samples obtained with the small forceps.

Genotyping in Small Biopsy Specimens
Discovery of driver mutations such as EGFR, $A L K$ and KRAS in the specimens from patients with NSCLC has revolutionized the management of NSCLC, especially adenocarcinoma. EGFR mutations have been proved to be a reliable predictive biomarker of both progression-free survival as well as tumor response to treatment with EGFR-tyrosine kinase inhibitors [15-17]. Similarly, ALK rearrangements are associated with progression-free survival and tumor response to treatment with ALK inhibitors [18]. In contrast to these molecular abnormalities, the clinical value of knowing KRAS mutations is still limited since the targeted therapies are still not available, although some promising agents which inhibit part of the $K R A S$ pathway are now being investigated $[22,34]$. A recent molecular testing guideline recommended EGFR mutation testing or suggested $A L K$ rearrangement testing at the time of diagnosis in patients with advanced-stage disease who are suitable for therapy [22]. Moreover, even in patients with early-stage disease, the EGFR mutation or $A L K$ rearrangement testing at diagnosis is encouraged 
Table 4. Cases with discordant genotypes between bronchoscopic and surgical specimens

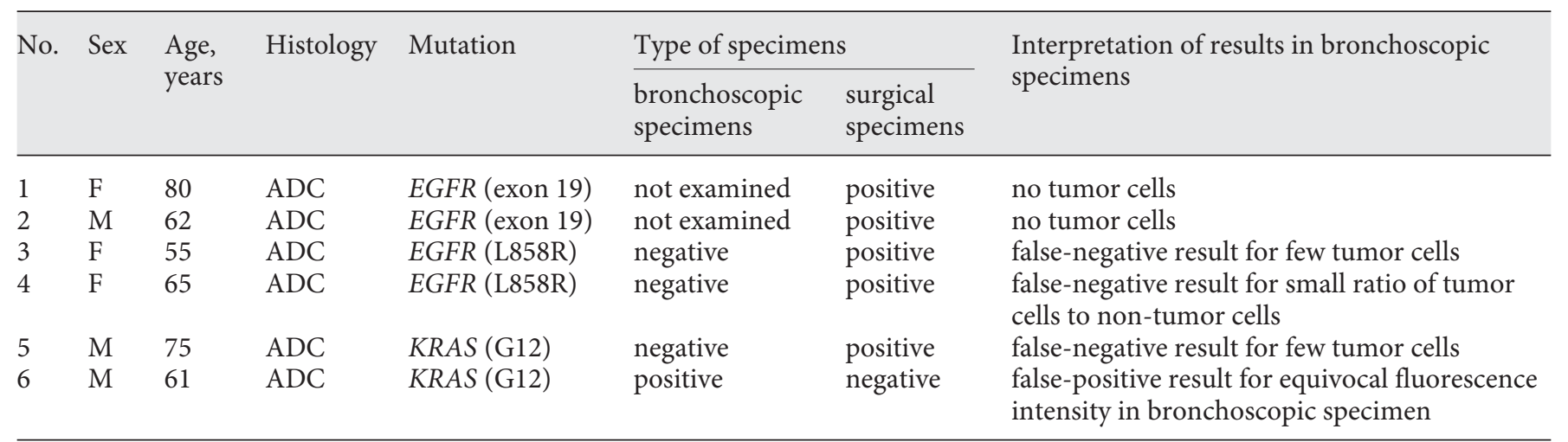

$\mathrm{ADC}=$ Adenocarcinoma

as the results may provide some benefits in terms of portability [22]. Thus, not only high yield for definitive diagnosis but also high feasibility and reliability for molecular testing is indispensable as a first diagnostic test. Nowadays, numerous types of cytologic and histologic samples can be used for molecular testing [35]. Above all, formalin-fixed paraffin-embedded samples, as we used in this study, have been most widely used for molecular testing as they have numerous advantages such as ease of use, long-time storage and low costs [14]. In fact, we used paraffin-embedded specimens preserved for more than 2 years without any special storage techniques. The feasibility of molecular testing in long-time stored specimens seems to be very important because new driver mutation genes and targeted therapies are developing one after another. The feasibility and reliability of molecular testing using bronchoscopic specimens such as specimens obtained with aspiration standard biopsy forceps or aspiration needles are well established [35]. Our study further demonstrated the usefulness of relatively smaller bronchoscopic specimens with fewer tumor cells obtained by small biopsy forceps for molecular testing.

In this study, 5 patients failed genotyping with bronchoscopic specimens due to an insufficient number of tumor cells. Although we regularly biopsied 8-10 tissue samples in individual patients $[8,11,13]$, the specimens in the 5 patients only had a few tumor cells that did not allow molecular testing. Resectioning of the tissue blocks could waste the tissues, and might reduce a number of tumor cells in some instances. Because diagnostic hematoxylin and eosin staining slides are made of unstained slides, preparation of additional unstained slides might serve to increase the feasibility. Therefore, it might be an alternative way to submit the specimens with ordering simultaneous histological diagnosis and molecular testing, based on the potential benefit of molecular testing. In terms of PCR failure, it is well known that the PCR based on formalin-fixed paraffin-embedded samples is affected by fixation time, fixation solution, and the duration of ischemic time and tissue processing techniques including decalcification using strong acids $[14,21,22,29]$. In fact, the surgical specimen in the patient showing PCR failure contained the costal bone where the tumor cells invaded, suggesting that the tissues were treated with decalcification solution. In the case of bronchoscopic specimens, inadequate fixation duration might cause PCR failure. Because biopsied tissues are usually tiny in contrast to the surgical specimens, the fixation that is optimized for surgical specimens could be too long for biopsy specimens. Careful management according to the sample size might be needed [14, 19-22].

As shown in table 4, the result of genotyping in the surgical specimens and bronchoscopic specimens was discordant in 6 patients. EGFR mutations in the bronchoscopic specimens were not analyzed in 2 patients as the specimens did not contain tumor cells. Two patients (1 $K R A S$-negative patient and $1 E G F R$-negative patient in the bronchoscopic specimens but positive in surgical specimens) had bronchoscopic specimens with few tumor cells in which the mutated signal might be below the detection threshold for mutations. As shown in figure 1, 1 patient with bronchoscopic specimens with a slight increase in fluorescence intensity was judged as KRAS positive; however, this result was regarded as false-positive from the negative result in surgical specimens. The re- 
maining patient was judged as EGFR negative in bronchoscopic specimens with a sufficient amount of tumor cells. Although the reason is unclear, this might be due to the small ratio of tumor cells to nontumor cells. Mutant DNA needs to comprise approximately $1 \%$ of the total DNA using DNA-based assays to detect mutations [36]. If the specimen contains a high percentage of nontumor cells, false-negative results may occur, even in specimens with a sufficient amount of tumor cells [37]. Certainly, the number of tumor cells would be associated with the success/failure of molecular testing. Folch et al. [28] compared the amount of tumor cells in the cell block specimens sampled by endobronchial ultrasound-transbronchial needle aspiration between the molecular testing failure group and the success group, and found that a specimen with less than 100 tumor cells per slide was associated with the failure of molecular testing. However, the detection threshold varies according to the detection methods. Actually, a clear positive reaction in a single cell is considered to be positive with $A L K$ immunohisto- chemistry. Interpretation of the negative mutation results in specimens with few tumor cells, so the small ratio of tumor cells to nontumor cells or equivocal results of molecular testing demands great caution. Molecular pathologists should alert the attending physicians about the quality of the molecular testing so as not to cause falsenegative or false-positive results.

In conclusion, bronchoscopic specimens obtained by the small biopsy forceps are feasible for genotyping of NSCLC in most cases. The results in the bronchoscopic specimens, in which the genotype could be evaluated, correlated well with those in surgically resected specimens. The clinical use of the small biopsy forceps during bronchoscopy can therefore be justified in terms of high feasibility and accuracy for molecular testing.

\section{Financial Disclosure and Conflicts of Interest}

None of the authors has any conflict of interest to disclose.

\section{References}

1 Rivera MP, Mehta AC, Wahidi MM: Establishing the diagnosis of lung cancer: diagnosis and management of lung cancer, 3rd ed: American College of Chest Physicians Evidence-Based Clinical Practice Guidelines. Chest 2013;143(suppl 5):e142S-e165S.

2 Gould MK, Donington J, Lynch WR, Mazzone PJ, Midthun DE, Naidich DP, Wiener RS: Evaluation of individuals with pulmonary nodules: when is it lung cancer?: diagnosis and management of lung cancer, 3rd ed: American College of Chest Physicians Evidence-Based Clinical Practice Guidelines. Chest 2013;143(suppl 5):e93S-e120S.

-3 Asahina H, Yamazaki K, Onodera Y, Kikuchi E, Shinagawa N, Asano F, Nishimura M: Transbronchial biopsy using endobronchial ultrasonography with a guide sheath and virtual bronchoscopic navigation. Chest 2005; 128:1761-1765.

-4 Yoshikawa M, Sukoh N, Yamazaki K, Kanazawa K, Fukumoto S, Harada M, Kikuchi E, Munakata $M$, Nishimura $M$, Isobe $H$ : Diagnostic value of endobronchial ultrasonography with a guide sheath for peripheral pulmonary lesions without X-ray fluoroscopy. Chest 2007; 131:1788-1793.

5 Yamada N, Yamazaki K, Kurimoto N, Asahina H, Kikuchi E, Shinagawa N, Oizumi S, Nishimura M: Factors related to diagnostic yield of transbronchial biopsy using endobronchial ultrasonography with a guide sheath in small peripheral pulmonary lesions. Chest 2007;132:603-608
6 Eberhardt R, Anantham D, Ernst A, FellerKopman D, Herth F: Multimodality bronchoscopic diagnosis of peripheral lung lesions: a randomized controlled trial. Am J Respir Crit Care Med 2007;176:36-41.

7 Asano F, Matsuno Y, Tsuzuku A, Anzai M, Shinagawa N, Yamazaki K, Ishida T, Moriya $\mathrm{H}$ : Diagnosis of peripheral pulmonary lesions using a bronchoscope insertion guidance system combined with endobronchial ultrasonography with a guide sheath. Lung Cancer 2008;60:366-373.

-8 Oki M, Saka H, Kitagawa C, Kogure Y, Mori K, Kajikawa S: Endobronchial ultrasoundguided transbronchial biopsy using novel thin bronchoscope for diagnosis of peripheral pulmonary lesions. J Thorac Oncol 2009;4:12741277.

-9 Mizugaki H, Shinagawa N, Kanegae K, Yamada N, Asahina H, Kikuchi E, Oizumi S, Tamaki N, Nishimura M: Combining transbronchial biopsy using endobronchial ultrasonography with a guide sheath and positron emission tomography for the diagnosis of small peripheral pulmonary lesions. Lung Cancer 2010;68:211-215.

10 Ishida T, Asano F, Yamazaki K, Shinagawa N, Oizumi S, Moriya H, Munakata M, Nishimura $M$, Virtual Navigation in Japan Trial Group: Virtual bronchoscopic navigation combined with endobronchial ultrasound to diagnose small peripheral pulmonary lesions: a randomised trial. Thorax 2011;66:10721077.
11 Oki M, Saka H, Kitagawa C, Kogure Y, Murata N, Adachi T, Ando M: Randomized study of endobronchial ultrasound-guided transbronchial biopsy: thin bronchoscopic method versus guide sheath method. J Thorac Oncol 2012;7:535-541.

12 Shinagawa N, Nakano K, Asahina H, Kikuchi E, Ito T, Matsuno Y, Oizumi S, Nasuhara Y, Nishimura M: Endobronchial ultrasonography with a guide sheath in the diagnosis of benign peripheral diseases. Ann Thorac Surg 2012;93:951-957.

13 Oki M, Saka H, Kitagawa C, Tanaka S, Shimokata T, Mori K, Kajikawa S: Novel thin bronchoscope with a $1.7-\mathrm{mm}$ working channel for peripheral pulmonary lesions. Eur Respir J 2008;32:465-471.

14 Thunnissen E, Kerr KM, Herth FJ, Lantuejoul S, Papotti M, Rintoul RC, Rossi G, Skov BG, Weynand B, Bubendorf L, Katrien G, Johansson L, López-Ríos F, Ninane V, Olszewski W, Popper H, Jaume S, Schnabel P, Thiberville L, Laenger F: The challenge of NSCLC diagnosis and predictive analysis on small samples. Practical approach of a working group. Lung Cancer 2012;76:1-18.

15 Mok TS, Wu YL, Thongprasert S, Yang CH, Chu DT, Saijo N, Sunpaweravong P, Han B, Margono B, Ichinose Y, Nishiwaki Y, Ohe Y, Yang JJ, Chewaskulyong B, Jiang H, Duffield EL, Watkins CL, Armour AA, Fukuoka M: Gefitinib or carboplatin-paclitaxel in pulmonary adenocarcinoma. N Engl J Med 2009; 361:947-957. 
$\checkmark 16$ Mitsudomi T, Morita S, Yatabe Y, Negoro S, Okamoto I, Tsurutani J, Seto T, Satouchi M, Tada H, Hirashima T, Asami K, Katakami N, Takada M, Yoshioka H, Shibata K, Kudoh S, Shimizu E, Saito H, Toyooka S, Nakagawa K, Fukuoka M, West Japan Oncology Group: Gefitinib versus cisplatin plus docetaxel in patients with non-small-cell lung cancer harbouring mutations of the epidermal growth factor receptor (WJTOG3405): an open label, randomised phase 3 trial. Lancet Oncol 2010; 11:121-128.

17 Maemondo M, Inoue A, Kobayashi K, Sugawara S, Oizumi S, Isobe H, Gemma A, Harada M, Yoshizawa H, Kinoshita I, Fujita Y, Okinaga S, Hirano $\mathrm{H}$, Yoshimori $\mathrm{K}$, Harada $\mathrm{T}$, Ogura T, Ando M, Miyazawa H, Tanaka T, Saijo Y, Hagiwara K, Morita S, Nukiwa T, North-East Japan Study Group: Gefitinib or chemotherapy for non-small-cell lung cancer with mutated EGFR. N Engl J Med 2010;362: 2380-2388.

18 Kwak EL, Bang YJ, Camidge DR, Shaw AT, Solomon B, Maki RG, Ou SH, Dezube BJ, Jänne PA, Costa DB, Varella-Garcia M, Kim WH, Lynch TJ, Fidias P, Stubbs H, Engelman JA, Sequist LV, Tan W, Gandhi L, Mino-Kenudson M, Wei GC, Shreeve SM, Ratain MJ, Settleman J, Christensen JG, Haber DA, Wilner K, Salgia R, Shapiro GI, Clark JW, Iafrate AJ: Anaplastic lymphoma kinase inhibition in non-small-cell lung cancer. N Engl J Med 2010;363:1693-1703.

-19 Pirker R, Herth FJ, Kerr KM, Filipits M, Taron M, Gandara D, Hirsch FR, Grunenwald D, Popper H, Smit E, Dietel M, Marchetti A, Manegold C, Schirmacher P, Thomas M, Rosell R, Cappuzzo F, Stahel R, European EGFR Workshop Group: Consensus for EGFR mutation testing in non-small cell lung cancer: results from a European workshop. J Thorac Oncol 2010;5:1706-1713.

-20 Travis WD, Brambilla E, Noguchi M, Nicholson AG, Geisinger KR, Yatabe Y, Beer DG, Powell CA, Riely GJ, Van Schil PE, Garg K, Austin 3JH, Asamura H, Rusch VW, Hirsch FR, Scagliotti G, Mitsudomi T, Huber RM, Ishikawa Y, Jett J, Sanchez-Cespedes M, Sculier JP, Takahashi T, Tsuboi M, Vansteenkiste J, Wistuba I, Yang PC, Aberle D, Brambilla C, Flieder D, Franklin W, Gazdar A, Gould M, Hasleton P, Henderson D, Johnson B, Johnson D, Kerr K, Kuriyama K, Lee JS, Miller VA, Petersen I, Roggli V, Rosell R, Saijo N, Thunnissen E, Tsao M, Yankelewitz D: International association for the study of lung cancer/ American Thoracic Society/European Respiratory Society international multidisciplinary classification of lung adenocarcinoma. J Thorac Oncol 2011;6:244-285.
21 Travis WD, Brambilla E, Noguchi M, Nicholson AG, Geisinger K, Yatabe Y, Ishikawa Y, Wistuba I, Flieder DB, Franklin W, Gazdar A, Hasleton PS, Henderson DW, Kerr KM, Petersen I, Roggli V, Thunnissen E, Tsao M: Diagnosis of lung cancer in small biopsies and cytology: implications of the 2011 International Association for the Study of Lung Cancer/American Thoracic Society/European Respiratory Society classification. Arch Pathol Lab Med 2013;137:668-684.

22 Lindeman NI, Cagle PT, Beasley MB, Chitale DA, Dacic S, Giaccone G, Jenkins RB, Kwiatkowski DJ, Saldivar JS, Squire J, Thunnissen E, Ladanyi M: Molecular Testing Guideline for Selection of Lung Cancer Patients for EGFR and ALK Tyrosine Kinase Inhibitors: Guideline from the College of American Pathologists, International Association for the Study of Lung Cancer, and Association for Molecular Pathology. J Thorac Oncol 2013;8: 823-859.

23 Masago K, Fujita S, Mio T, Ichikawa M, Sakuma K, Kim YH, Hatachi Y, Fukuhara A, Kamiyama K, Sonobe M, Miyahara R, Date H, Mishima M: Accuracy of epidermal growth factor receptor gene mutation analysis by direct sequencing method based on small biopsy specimens from patients with non-small cell lung cancer: analysis of results in 19 patients. Int J Clin Oncol 2008;13:442-446.

24 Nakajima T, Yasufuku K, Suzuki M, Hiroshima K, Kubo R, Mohammed S, Miyagi Y, Matsukuma S, Sekine Y, Fujisawa T: Assessment of epidermal growth factor receptor mutation by endobronchial ultrasound-guided transbronchial needle aspiration. Chest 2007;132: 597-602.

25 Sakairi Y, Nakajima T, Yasufuku K, Ikebe D, Kageyama H, Soda M, Takeuchi K, Itami M, Iizasa T, Yoshino I, Mano $\mathrm{H}$, Kimura $\mathrm{H}$ : EML4-ALK fusion gene assessment using metastatic lymph node samples obtained by endobronchial ultrasound-guided transbronchial needle aspiration. Clin Cancer Res 2010; 16:4938-4945.

26 Nakajima T, Yasufuku K, Nakagawara A, Kimura H, Yoshino I: Multigene mutation analysis of metastatic lymph nodes in nonsmall cell lung cancer diagnosed by endobronchial ultrasound-guided transbronchial needle aspiration. Chest 2011;140:1319-1324.
27 Navani N, Brown JM, Nankivell M, Woolhouse I, Harrison RN, Jeebun V, Munavvar M, Ng BJ, Rassl DM, Falzon M, Kocjan G, Rintoul RC, Nicholson AG, Janes SM: Suitability of endobronchial ultrasound-guided transbronchial needle aspiration specimens for subtyping and genotyping of non-small cell lung cancer: a multicenter study of 774 patients. Am J Respir Crit Care Med 2012; 185:1316-1322.

28 Folch E, Yamaguchi N, VanderLaan PA, Kocher ON, Boucher DH, Goldstein MA, Huberman MS, Kent MS, Gangadharan SP, Costa DB, Majid A: Adequacy of lymph node transbronchial needle aspirates using convex probe endobronchial ultrasound for multiple tumor genotyping techniques in non-small-cell lung cancer. J Thorac Oncol 2013;8:1438-1444.

29 Vanderlaan PA, Yamaguchi N, Folch E, Boucher DH, Kent MS, Gangadharan SP, Majid A, Goldstein MA, Huberman MS, Kocher ON, Costa DB: Success and failure rates of tumor genotyping techniques in routine pathological samples with non-small-cell lung cancer. Lung Cancer 2014;84:39-44.

30 Kossakowski CA, Morresi-Hauf A, Schnabel PA, Eberhardt R, Herth FJ, Warth A: Preparation of cell blocks for lung cancer diagnosis and prediction: protocol and experience of a highvolume center. Respiration 2014;87:432-438.

- 31 Yatabe Y, Hida T, Horio Y, Kosaka T, Takahashi T, Mitsudomi T: A rapid, sensitive assay to detect EGFR mutation in small biopsy specimens from lung cancer. J Mol Diagn 2006;8:335-341.

- 32 Fukui T, Yatabe Y, Kobayashi Y, Tomizawa K, Ito S, Hatooka S, Matsuo K, Mitsudomi T: Clinicoradiologic characteristics of patients with lung adenocarcinoma harboring EML4ALK fusion oncogene. Lung Cancer 2012;77: 319-325.

- 33 Murakami Y, Mitsudomi T, Yatabe Y: A screening method for the ALK fusion gene in NSCLC. Front Oncol 2012;2:24.

34 Roberts PJ, Stinchcombe TE: KRAS mutation: should we test for it, and does it matter? J Clin Oncol 2013;31:1112-1121.

35 Ellison G, Zhu G, Moulis A, Dearden S, Speake G, McCormack R: EGFR mutation testing in lung cancer: a review of available methods and their use for analysis of tumour tissue and cytology samples. J Clin Pathol 2013;66:79-89.

-36 Pao W, Ladanyi M: Epidermal growth factor receptor mutation testing in lung cancer: searching for the ideal method. Clin Cancer Res 2007;13:4954-4955.

- 37 Yatabe Y, Matsuo K, Mitsudomi T: Heterogeneous distribution of EGFR mutations is extremely rare in lung adenocarcinoma. J Clin Oncol 2011;29:2972-2977. 